\title{
Ionic Composition in Aqueous Extracts from PM2.5 in Ambient Air at the City of Cuernavaca, México
}

\author{
Hugo Saldarriaga-Noreña ${ }^{*}$, Leonel Hernández-Mena², Enrique Sánchez-Salinas ${ }^{3}$, \\ Fernando Ramos-Quintana ${ }^{3}$, Laura Ortíz-Hernández ${ }^{3}$, Rodrigo Morales-Cueto ${ }^{1}$, \\ Vanesa Alarcón-González ${ }^{1}$, Sandra Ramírez-Jiménez ${ }^{1}$ \\ ${ }^{1}$ Chemical Research Center, Autonomous University of the Morelos State, Cuernavaca, Mexico \\ ${ }^{2}$ Center for Research and Assistance in Technology and Design of the State of Jalisco, Guadalajara, Mexico \\ ${ }^{3}$ Biotechnology Research Center, Autonomous University of the Morelos State, Cuernavaca, Mexico \\ Email: ${ }^{\text {hsaldarriaga@uaem.mx }}$
}

Received 11 August 2014; revised 8 September 2014; accepted 1 October 2014

Copyright (C) 2014 by authors and Scientific Research Publishing Inc.

This work is licensed under the Creative Commons Attribution International License (CC BY).

http://creativecommons.org/licenses/by/4.0/

(c) (i) Open Access

\section{Abstract}

The present study was carried out between May and June 2012 in the city of Cuernavaca, Mexico. During this time the average ambient temperatures were about $25^{\circ} \mathrm{C}$, suggesting the formation of secondary aerosols, consisting mainly of ammonium and sulfate. The average PM2.5 concentration was $37 \mu \mathrm{g} \cdot \mathrm{m}^{-3}$ for the entire urban area and there were only two days which exceeded the limit established by the official standards for periods of $24 \mathrm{~h}$. The most abundant ionic species associated with PM2.5 were sulfates $\left(3634.82 \mathrm{ng} \cdot \mathrm{m}^{-3}\right.$, average) and ammonium $\left(1709.53 \mathrm{ng} \cdot \mathrm{m}^{-3}\right.$, average). The ratio estimated between total anions and total cations indicated that the concentration of total anions was 1.94 times total cations. The contribution percentage of the ionic species associated with PM2.5 revealed that $76 \%$ of the PM2.5 is sulfates and ammonium. The ion balance made for the urban area of Cuernavaca indicated that during the study period, the aerosols showed alkaline characteristics; that is to say the concentration of anions was not sufficient to neutralize the cations, specifically ammonia $(m=0.060)$. Finally, wind fields showed that during the study the winds came in $50 \%$ from the south west, followed by $25 \%$ from east and $12.5 \%$ of the south east, which in part allowed transport of contaminants into the portion of the city, where the AUSM campus site was located.

\section{Keywords}

Ionic species, Cuernavaca, Ion Balance

\footnotetext{
${ }^{*}$ Corresponding author.

How to cite this paper: Saldarriaga-Noreña, H., Hernández-Mena, L., Sánchez-Salinas, E., Ramos-Quintana, F., OrtízHernández, L., Morales-Cueto, R., Alarcón-González, V. and Ramírez-Jiménez, S. (2014) Ionic Composition in Aqueous Extracts from PM2.5 in Ambient Air at the City of Cuernavaca, México. Journal of Environmental Protection, 5, $1305-1315$. http://dx.doi.org/10.4236/jep.2014.513124
} 


\section{Introduction}

The study of atmospheric aerosols has become important in recent years due to their influence on the global climate directly by scattering or absorption of solar radiation and indirectely by altering cloud microphysics and the water cycle. Also, they influence atmospheric chemistry and cause negative effects on human health [1]-[7].

Specifically, particles less than or equal to 2.5 microns (PM2.5) consist largely of water-soluble ionic species $\left(\mathrm{SO}_{4}^{2-}, \mathrm{NO}_{3}^{-}, \mathrm{Cl}^{-}, \mathrm{NH}_{4}^{+}\right.$), but also exhibit a significant insoluble fraction consisting of organic compounds (OC), elemental carbon (EC) and trace metals ( $\mathrm{Hg}, \mathrm{Pb}, \mathrm{As}, \mathrm{Cd}, \mathrm{Sb}$, etc.) [8] [9]. The complex chemical composition of atmospheric aerosols can be attributed to the diversity of emission sources and the prevailing environmental factors. The source can be natural or anthropogenic and can be emitted directly into the atmosphere or formed secondarily from gaseous precursors. The study of particle concentration and its composition is essential for the identification of emission sources, likewise for the processes associated with their formation [10]-[12].

In México there are standards for air quality for the following air pollutants: sulfur dioxide $\left(\mathrm{SO}_{2}\right)$, carbon monoxide (CO), nitrogen dioxide $\left(\mathrm{NO}_{2}\right)$, ozone $\left(\mathrm{O}_{3}\right)$, total suspended particles (TSP), particulate matter less than ten microns in diameter (PM10) and lead (Pb).

The city of Cuernavaca is not the exception to the current situation of deterioration in air quality; in that in recent years, this urban area has significantly increased its population and the number of human activities, which generate large amounts of air pollutants.

Actually, in order to contribute to environmental improvement in the state, the government has been promoting and supporting environmental studies aimed at the development of diagnostics of the ambient levels of some pollutants considered of high risk to human health and the environment. This was done in order to allow for the design of control programs and/or to mitigate in the short and medium term. Therefore, this study was developed which aims to identify the chemical composition of particulate matter (PM2.5), and to serve as a precedent for further research.

\section{Materials and Methods}

\subsection{Sampling Sites}

Three sampling sites within the urban area of the city of Cuernavaca were selected. Each one is characterized by different activities, such as vehicular and industrial, in addition to having different geographical and topographical features. The sites selected were: Centro, located in the downtown of the city, the North Campus of the Autonomous University of the State of Morelos (AUSM), located north of the city, and an attached high school Campus of the AUSM (Preparatoria 1), located to the southeast of the metropolitan area. The Centro site is influenced by high vehicular and service activity, while the Preparatoria 1 site is characterized by high vehicular traffic as well as industrial impact, given that there exists an industrial park nearby named CIVAC (Centro Industrial de la Ciudad de Cuernavaca, for its acronym in Spanish).

The North Campus (AUSM) site is characterized by being on the edge of the metropolitan area, on slopes, which suggests frequent movements of air and thus contaminant transport. This area has abundant vegetation; however it is highly influenced by the Mexico-Cuernavaca highway, which passes on one side, and the transport of pollutants, specifically from Mexico City and the south side of the city.

\subsection{Sampling of PM2.5}

Sampling of PM2.5 was conducted between May 18 and June 30, 2012. For the Preparatoria 1 and Centro sites, low volume equipment (Mini-Vol, Airmetrics), were used, at a flow rate $5 \mathrm{~L} \cdot \mathrm{min}^{-1}$, with quartz filters for particle collection. While at the AUSM site, PQ-200 equipment (Waltham, BGI, Inc.) was used at a flow of $16.4 \mathrm{~L} \cdot \mathrm{min}^{-1}$, also with filters of $47 \mathrm{~mm}$ diameter. In all cases sampling was conducted for periods of $24 \mathrm{~h}$.

The difference in filter weights was obtained under controlled conditions of temperature and relative humidity, before and after sampling, and allowed for the determination of the mass of PM2.5 and estimation of its concentrations in ambient air (corrected to standard conditions of temperature and pressure).

\subsection{Ionic Species Analysis and Quality Control}

Samples were extracted with Milli-Q water (18.2 M $)$ ), in an ultrasonic bath (Branson 5510) for 1 hour. Extracts 
were filtered through nylon membranes $(0.45 \mu \mathrm{m}$ pore diameter $)$ and transferred to vials for chemical analysis by ion chromatography. The ionic composition was determined by an ion chromatograph (Dionex, 1600 with ISC Conductivity Detector).

The anions $\left(\mathrm{SO}_{4}^{2-}, \mathrm{NO}_{3}^{-}, \mathrm{Cl}^{-}, \mathrm{PO}_{4}^{3-}, \mathrm{NO}_{2}^{-}\right.$) were analyzed by chemical suppression with a Dionex IonPac AS18-4 $\mu \mathrm{m}$ column; the mobile phase used was a solution of sodium carbonate-sodium bicarbonate $(0.35: 0.1$ $\mathrm{M}$ ), at a flow rate of $1 \mathrm{~mL} \cdot \mathrm{min}^{-1}$. Meanwhile, the cations $\left(\mathrm{NH}_{4}^{+}, \mathrm{Na}^{+}, \mathrm{K}^{+}, \mathrm{Ca}^{2+}, \mathrm{Mg}^{2+}\right)$ were determined without chemical suppression, using a Dionex IonPac CS16 column; the mobile phase was $26.0 \mathrm{mM}$ methasulfonic acid, at a flow rate of $1 \mathrm{~mL} \cdot \mathrm{min}^{-1}$. For quantification of all species, calibration curves were performed in a concentration range between 0.0625 and $10 \mu \mathrm{g} \cdot \mathrm{mL}^{-1}$. The detection limits for anions were between 0.035 and 0.277 $\mu \mathrm{g} \cdot \mathrm{mL}^{-1}$ and for cations between 0.01 and $0.166 \mu \mathrm{g} \cdot \mathrm{mL}^{-1}$.

\subsection{Back Trajectories}

The Hybrid Single-Particle Lagrangian Integrated Trajectory (HYSPLIT4) model, obtained from the National Oceanic and Atmospheric Administration (NOAA), was used to calculate the wind trajectories. Trajectories tracing back 3 days (72 hr) were calculated. Each trajectory was estimated at $400 \mathrm{~m}$ above ground level.

\subsection{Statistical Analysis}

The data obtained from the variables of interest for this study were mainly analyzed with nonparametric statistical tests. The Mann-Whitney U test was applied to compare two sets of data, while the Kruskal-Wallis test was used for comparison of PM2.5 data, anions and cations between the three sampling sites. The Spearman correlation coefficient ( $\boldsymbol{r}$ ) established the level of the relationship between the variables, whereas the analysis of linear regression by least squares method allowed the determination of the degree of neutralization between anions and cations, as well as determining the degree of acidity or alkalinity of the particles.

\section{Results and Discussion}

\subsection{Back Trajectories and Potential Sources of Contaminants}

To identify the transport pathways of air masses from different potential source regions, backward air trajectory analysis was carried out using the HYSPLIT 4.8 model. Four types of trajectories were observed during sampling period for the city of Cuernavaca. The South West (SW) trajectory prevailed from May 18 to June 30 (50\%), it suggests that air masses are transporting some contaminants from the Centro site (SW), to the north of the city where the anthropogenic activities are important; the AUSM site is located in this direction. The East (E) type, accounting for $25 \%$ of all trajectories, indicates that a possible source in Cuernavaca is volcanic emissions from the Popocatepetl volcano. For its part, the South East (SE) type, contributes with $12.5 \%$ of all trajectories, passing over the Preparatoria 1 site, where industrial and vehicular activities are a constant feature (Figure 1).

\subsection{PM2.5 Concentration}

The median of the concentrations of PM2.5, for the entire study period and the three sampling sites, was 28 $\mu \mathrm{g} \cdot \mathrm{m}^{-3}$ (average of $37 \mu \mathrm{g} \cdot \mathrm{m}^{-3}$ ). Table 1 shows the descriptive statistics of the variation of the concentrations determined in each of the three sampling sites in the city of Cuernavaca. The analysis of these data by using the Kruskal-Wallis test confirmed the absence of significant differences between the data sets of particle concentration at each site $(\mathrm{p}=0.76)$. These results suggest that for the sampling period, the concentration of PM2.5 was homogeneous in a large part of the city of Cuernavaca.

In Mexico the Official Mexican Standard (NOM-025-SSA1-1993) establishes the average maximum concentration of PM2.5 $\left(65 \mu \mathrm{g} \cdot \mathrm{m}^{-3}\right)$ for a period of $24 \mathrm{~h}$. The UAEM and Centro sites exceeded this limit, each twice reaching 90 and $75 \mu \mathrm{g} \cdot \mathrm{m}^{-3}$, respectively, while the Preparatoria 1 site did not exceeded the standard established by the norm on any sampling day. It is likely that at this latter site meteorological and climatic conditions have been more favorable for the dispersion of pollutants, specifically on days with high particulate concentrations in ambient air.

In addition, Table 1 shows the concentration levels of PM2.5 reported in other Mexican cities and other places in the world. The concentrations reported in other cities are similar, qualitatively, and serve as reference levels to 


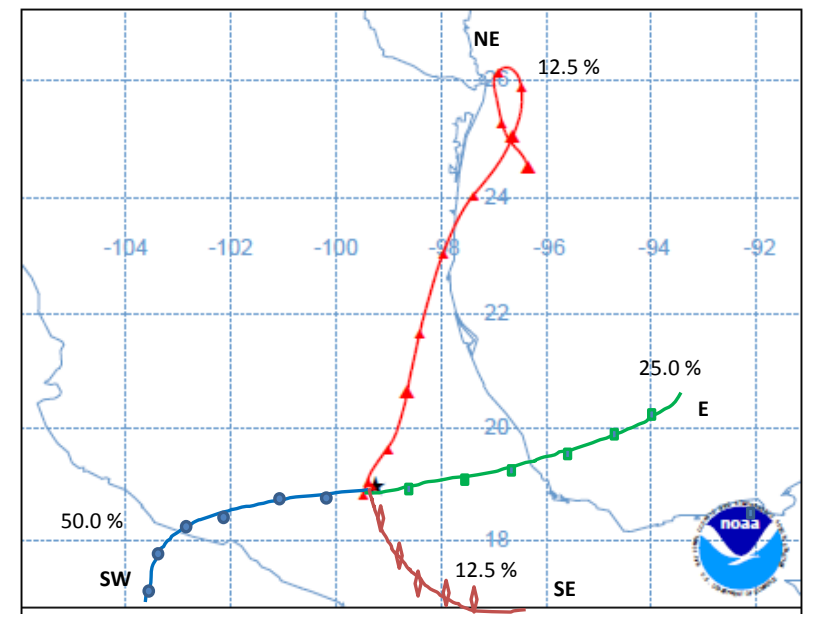

Figure 1. Typical back trajectories at Cuernavaca city from May 18 to June 30, 2012.

Table 1. Comparison of the concentration of PM2.5 with other sites around the world $\left(\mu \mathrm{g} \cdot \mathrm{m}^{-3}\right)$.

\begin{tabular}{|c|c|c|c|c|c|c|c|}
\hline & $\mathrm{N}$ & Average & Median & Minimum & Maximum & $\mathrm{SD}$ & Type of area \\
\hline AUSM & 6 & 36 & 19 & 4 & 90 & 37 & Urban \\
\hline Centro & 6 & 43 & 38 & 7 & 75 & 27 & Urban \\
\hline Preparatoria $^{1}$ & 7 & 34 & 28 & 11 & 56 & 16 & Urban \\
\hline Cuernavaca-Morelos* & 19 & 37 & 28 & 4 & 90 & 26 & Urban \\
\hline México City ${ }^{1}$ & 27 & 36 & & & & 10.1 & Urban \\
\hline 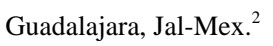 & 73 & 48 & & & & 20.1 & Urban \\
\hline \multirow[t]{2}{*}{ Pamplona, España ${ }^{3}$} & & 15.4 & & 3.9 & 74.9 & & Urban \\
\hline & & 17.4 & & 3.6 & 86.3 & & Urban \\
\hline \multirow[t]{3}{*}{ Hong Kong ${ }^{4}$} & & 69.3 & & & & 11.8 & Urban \\
\hline & & 66.9 & & & & 12.3 & Urban \\
\hline & & 49.3 & & & & 17.9 & Urban \\
\hline Berna $^{5}$ & & 24.6 & & & & & Urban \\
\hline Zurich $^{5}$ & & 43.0 & & & & & Urban \\
\hline Basel $^{5}$ & & 18.9 & & & & & Urban \\
\hline Payern $^{5}$ & & 13.7 & & & & & Suburban \\
\hline Chaumont $^{5}$ & & 7.7 & & & & & Suburban \\
\hline Turín $^{6}$ & & 69.2 & 70.2 & & & 13.7 & Urban \\
\hline Verona $^{6}$ & & 51.0 & 60.9 & & & 17.5 & Urban \\
\hline Barcelona $^{6}$ & & 30.2 & 31.9 & & & 5.6 & Urban \\
\hline París $^{6}$ & & 21.0 & 18.0 & & & 10.9 & Urban \\
\hline Reykjavik $^{6}$ & & 4.8 & 4.6 & & & 2.0 & Suburban \\
\hline
\end{tabular}

*This study. SD—standard deviation; N—sampling number. ${ }^{1}$ Edgerton et al. (2000); ${ }^{2}$ Hernández et al. (2009), two sampling sites; ${ }^{3}$ Aldabe et al. (2011), two sampling sites; ${ }^{4}$ Cheng et al. (2010), three sampling sites; ${ }^{5}$ Hueglin et al. (2005), three sampling sites; ${ }^{6} \mathrm{Hazenkamp-von} \mathrm{Arx} \mathrm{et} \mathrm{al.} \mathrm{(2003).}$

those observed in the different sites sampled in Cuernavaca. It is important to mention that comparisons should be made with caution because of differences in population size, number of sources and types, topography, etc.

\subsection{Ion Species in Aqueous Extracts in PM2.5}

In total five inorganic anions and five cations were analyzed in aqueous extracts obtained from PM2.5 particles collected at three different sites in the city of Cuernavaca. After determining their concentrations in ambient air, it was determined that the concentration of Total Anions (TA) was significantly greater than Total Cations (TC) 
(Mann-Whitney, $\mathrm{p}=0.00001$ ) during the entire period of sampling. These differences allowed for the estimation of the proportion of TA/TC, indicating that the TA concentration was 1.94 times higher than TC at all sampling sites. This ratio was statistically similar between the three study sites (1.84, 1.95 and 1.96 in Preparatoria 1, Centro and AUSM, respectively, $\mathrm{p}=0.364$ ). The above ratio only reflects the proportion of concentrations of both types of ions associated with PM2.5, but does not provide information about the chemical properties of the particles (see ion balance section).

Considering all data sets for the entire study, the most abundant ions were $\mathrm{SO}_{4}^{2-}$ and $\mathrm{NH}_{4}^{+}$. Species such as $\mathrm{Cl}^{-}, \mathrm{NO}_{2}^{-}, \mathrm{NO}_{3}^{-}, \mathrm{PO}_{4}^{3-}, \mathrm{Na}^{+}, \mathrm{K}^{+}, \mathrm{Ca}^{2+}$ and $\mathrm{Mg}^{2+}$, were below the levels determined for ammonium and sulfate (Table 2).

In general, all the cation and anion concentrations showed no significant differences between the three sites ( $>0.05$, in all cases); a behavior similiar to that observed with PM2.5. This probably suggests that the source of these chemical species, or atmospheric formation mechanisms, are similar within the urban area of Cuernavaca. In this regard Cheng et al. (2010) [13], mentions that homogeneous concentrations of secondary aerosols in the ambient air can be derived from the impact of dominant regional sources.

\subsection{Percentage Contribution of Ionic Species}

Taking into account the concentrations of anions and cations associated with PM2.5 and due to the absence of statistically significant differences of ions and particles between sites, the percentage contribution of anions and cations was estimated with respect to the total ion content (TI) for the urban area of Cuernavaca, considering the total data from the three sampling sites. The results indicated that ammonium and sulfate contributed 52 and $24 \%$, respectively ( $76 \%$ between the two species). Other ion species, individually, did not contribute more than $6 \%$ to the total. It is important to emphasize that these percentages may vary if the presence of other ion species is taken into account.

Figure 2 shows the estimated results of the percentage contribution of anions and cations in PM2.5. These results coincide with those reported by Ito et al. (2004), Hueglin et al. (2005), Cheng et al. (2010) [13]-[15] who indicate for different cities around the world that the sulfates, as well as a very limited number of species, contribute significantly to the concentrations of PM2.5. A similar result was also reported by Bell et al. (2007) [16] who, from a study of 187 communities in the United States noted that the sulfates and ammonium species were the main contributors to PM2.5, a similar situation to what was observed in this study.

In the city of Cuernavaca the precursors $\left(\mathrm{SO}_{2}\right.$ and $\left.\mathrm{NO}_{\mathrm{x}}\right)$ of the most abundant ions, ammonium and sulfate, are subject to oxidation processes once that they are emited to the atmosphere. Thus, it can be suggested that the different combustion processes contribute indirectly to the presence of sulfate and ammonium in the PM2.5, so

Table 2. Average concentration of anions and cations associated with PM2.5 in the urban area of Cuernavaca $\left(\mathrm{ng} \cdot \mathrm{m}^{-3}\right)$.

\begin{tabular}{|c|c|c|c|c|c|c|}
\hline Species & $\mathrm{N}$ & Average & Median & Minimum & Maximum & SD \\
\hline $\mathrm{Cl}^{-}$ & 29 & 172.39 & 84.55 & 51.96 & 1598.28 & 297.48 \\
\hline $\mathrm{NO}_{2}^{-}$ & 29 & 320.14 & 271.53 & 31.62 & 913.62 & 252.06 \\
\hline $\mathrm{NO}_{3}^{-}$ & 29 & 409.65 & 279.21 & 129.19 & 2200.27 & 422.73 \\
\hline $\mathrm{PO}_{4}^{3-}$ & 21 & 58.26 & 54.91 & 36.33 & 113.11 & 16.08 \\
\hline $\mathrm{SO}_{4}^{2-}$ & 29 & 3634.82 & 3880.91 & 923.83 & 6373.85 & 1601.92 \\
\hline $\mathrm{Na}^{+}$ & 29 & 177.04 & 123.75 & 54.20 & 1272.39 & 222.61 \\
\hline $\mathrm{NH}_{4}^{+}$ & 29 & 1709.53 & 1921.32 & 146.74 & 2947.36 & 763.18 \\
\hline $\mathrm{K}^{+}$ & 29 & 245.82 & 231.10 & 72.57 & 619.72 & 126.91 \\
\hline $\mathrm{Mg}^{2+}$ & 29 & 37.64 & 24.38 & 10.07 & 285.97 & 50.91 \\
\hline $\mathrm{Ca}^{2+}$ & 29 & 283.34 & 162.36 & 77.52 & 2594.05 & 458.32 \\
\hline Anions sum & 29 & 4579.19 & 4681.66 & 1308.06 & 10658.20 & 1998.61 \\
\hline Cations sum & 29 & 2453.39 & 2475.69 & 368.66 & 7560.88 & 1319.61 \\
\hline Total ions & 29 & 7032.58 & 7062.98 & 1676.72 & 18219.08 & 3276.62 \\
\hline
\end{tabular}

SD—standard deviation; N-sampling number. 


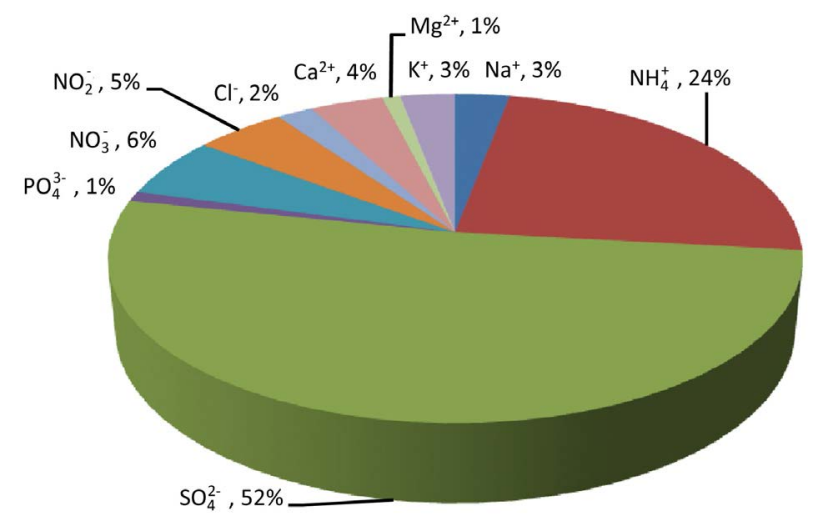

Figure 2. Percentage contribution of the ionic species in the urban area.

that anthropogenic activities become important as sources of these species [13] [17]. Such precursors are originated mainly from the combustion processes of gasoline derived from petroleum [18] [19]. This suggests that a portion of the ammonium and sulfate comes from the combustion process in this urban area. Furthermore, Aldabe et al. (2011) [20] suggest that the strong solar radition in spring and summer promotes the oxidation of $\mathrm{SO}_{2}$ to $\mathrm{SO}_{4}^{2-}$. This last condition was that which prevailed during the sampling months (May and June), in and around the city of Cuernavaca.

This situation probably contributed to the higher concentrations of sulfates with respect to the other ion species, including nitrates, which are also of secondary origin. Although $\mathrm{NO}_{3}^{-}$was one of the three most abundant ions considered in this study, the median concentrations was thirteen times less than the median concentrations of $\mathrm{SO}_{4}^{2-}$. Such a condition could be due to the warm climate that characterizes the city of Cuernavaca and does not favor the formation of nitrate in PM2.5 [21]. Aldabe et al. (2011) [20] and Bell et al. (2007) [16] report high concentration levels of nitrates in winter and low concentrations in summer in PM2.5, suggesting the likelihood that this condition is due to the low thermal stability of $\mathrm{NH}_{4} \mathrm{NO}_{3}$ in summer, under warm conditions where $\mathrm{HNO}_{3}$ formation is favored [20]. A longer study of the composition of ions associated with PM2.5 would confirm this condition in the city of Cuernavaca and also yield information about the temporal variation of nitrate in PM2.5.

In the background species such as $\mathrm{Ca}^{2+}$ and $\mathrm{Mg}^{2+}$ appear, which are primarily associated with a geological origin (resuspension of soil dust due to wind or vehicular traffic), indicating a contribution of natural sources to the chemical composition of PM2.5 [17] [22]-[24]. Also it is observed that the presence of $\mathrm{Cl}^{-}$suggests that this may come from combustion emissions during cooking, coal cars, vegetation burning and incineration [25] [16] The presence of $\mathrm{K}^{+}$in the aqueous extracts from PM2.5 may well have a geological origin, or to be related to emissions from biomass burning [26]. It is likely that for the city of Cuernavaca part of the $\mathrm{K}^{+}$could be originated from soil particles, due to the significant correlation with $\mathrm{Ca}^{2+}[26]$.

\subsection{Correlation between Species of Anions and Cations}

To evaluate the degree of association between the anion and cation species, the entire data set was used to calculate the Spearman's rank correlation, "r".

Table 3 shows the results of this analysis. The values in bold for " $r$ " were significant $(p<0.05)$. Highlighted among these values are the correlation coefficients between the concentrations of sulfate and ammonium $(\mathrm{r}=$ $0.99, \mathrm{p}<0.05)$, and those concentrations with TA, TC and TI $(r=0.97,0.96,0.98$ and $r=0.93,0.96$, 0.94, respectively, in all cases $\mathrm{p}<0.05$ ). High values obtained for these factors indicate that the variation of the total ion content can be sufficiently explained by the variation in the content of ammonium and sulfates in PM2.5, which were the most abundant in this study.

Moreover, a linear regression analysis was performed by the least squares method between the levels of anions and cations concentrations, expressed as $\mathrm{nM} / \mathrm{m}^{3}$ (nanomolar per $\mathrm{m}^{3}$ ). This was done with the intention of evaluating the presence of chemical neutralization processes between these species. From this analysis, those results were taken with values of $r>0.82$ between anions and cations. The linear regression analysis suggested 
Table 3. Correlations between ionic species determined at Cuernavaca.

\begin{tabular}{|c|c|c|c|c|c|c|c|c|c|c|c|c|c|c|}
\hline & $\mathrm{Cl}^{-}$ & $\mathrm{NO}_{2}^{-}$ & $\mathrm{NO}_{3}^{-}$ & $\mathrm{PO}_{4}^{3-}$ & $\mathrm{SO}_{4}^{2-}$ & $\mathrm{Na}^{+}$ & $\mathrm{NH}_{4}^{+}$ & $\mathrm{K}^{+}$ & $\mathrm{Mg}^{2+}$ & $\mathrm{Ca}^{2+}$ & PM2.5 & $\mathrm{TA}$ & $\mathrm{TC}$ & TI \\
\hline $\mathrm{Cl}^{-}$ & 1.00 & & & & & & & & & & & & & \\
\hline $\mathrm{NO}_{2}^{-}$ & 0.22 & 1.00 & & & & & & & & & & & & \\
\hline $\mathrm{NO}_{3}^{-}$ & 0.38 & 0.60 & 1.00 & & & & & & & & & & & \\
\hline $\mathrm{PO}_{4}^{3-}$ & 0.62 & 0.43 & 0.61 & 1.00 & & & & & & & & & & \\
\hline $\mathrm{SO}_{4}^{2-}$ & 0.44 & 0.56 & 0.60 & 0.65 & 1.00 & & & & & & & & & \\
\hline $\mathrm{Na}^{+}$ & 0.78 & 0.40 & 0.63 & 0.61 & 0.71 & 1.00 & & & & & & & & \\
\hline $\mathrm{NH}_{4}^{+}$ & 0.46 & 0.49 & 0.55 & 0.63 & 0.99 & 0.69 & 1.00 & & & & & & & \\
\hline $\mathrm{K}^{+}$ & 0.66 & 0.39 & 0.63 & 0.68 & 0.74 & 0.83 & 0.73 & 1.00 & & & & & & \\
\hline $\mathrm{Mg}^{2+}$ & 0.58 & 0.31 & 0.50 & 0.69 & 0.54 & 0.66 & 0.53 & 0.71 & 1.00 & & & & & \\
\hline $\mathrm{Ca}^{2+}$ & 0.32 & 0.42 & 0.56 & 0.70 & 0.61 & 0.55 & 0.57 & 0.63 & 0.70 & 1.00 & & & & \\
\hline PM2.5 & 0.46 & 0.47 & 0.16 & 0.36 & 0.08 & 0.15 & 0.09 & 0.24 & 0.15 & 0.53 & 1.00 & & & \\
\hline TA & 0.12 & 0.45 & 0.56 & 0.42 & 0.97 & 0.59 & 0.93 & 0.62 & 0.38 & 0.53 & -0.19 & 1.00 & & \\
\hline TC & 0.29 & 0.28 & 0.47 & 0.59 & 0.96 & 0.66 & 0.96 & 0.72 & 0.51 & 0.64 & -0.06 & 0.94 & 1.00 & \\
\hline TI & 0.17 & 0.41 & 0.54 & 0.42 & 0.98 & 0.63 & 0.94 & 0.68 & 0.43 & 0.59 & -0.06 & 0.99 & 0.97 & 1.00 \\
\hline
\end{tabular}

Bold and italics values $(\mathrm{p}<0.05)$.

that sulfate concentrations are partly neutralized with the ammonia present in the particles $\left(\mathrm{R}^{2}=0.97, \mathrm{p}<\right.$ $0.00001)$, and it is highly probable that these species have been present as ammonium sulfate $\left(\left(\mathrm{NH}_{4}\right)_{2}\left(\mathrm{SO}_{4}\right)\right)$. Figure 3 represents the process of neutralization between sulfates and ammonium. Other compounds probably found in the PM2.5 are sodium chloride $\left(\mathrm{R}^{2}=0.86\right)$, magnesium chloride $\left(\mathrm{R}^{2}=0.88\right)$, calcium chloride $\left(\mathrm{R}^{2}=\right.$ 0.79 ) and calcium phosphate $\left(R^{2}=0.67\right)$, in all cases with $p<0.00001$. These results give evidence for the existence of neutralization between different species of anions and cations present in the PM2.5, thus this is an important factor in the formation of secondary compounds that comprise these particulate contaminants. The neutralization processes of these species in the atmosphere can be subject to variations in the environmental factors and the availability of their chemical precursors [27].

\subsection{Ion Balance}

In order to establish the acidic or basic properties of the aerosols in the urban area of Cuernavaca, the concentrations of the ionic species tested were transformed to $\mathrm{nEq} / \mathrm{m}^{3}$ (nanoequivalents per $\mathrm{m}^{3}$ ).

After realizing the transformation to $\mathrm{nEq} / \mathrm{m}^{3}$ units and applying a linear regression analysis of least squares method, a value for the slope $(\mathrm{m})$ less than unity $(\mathrm{m}=0.60, \mathrm{p}<0.00001)$ was found. This result indicates that during the sampling campaign, the concentration of anions was not enough to neutralize the ammonia and other species of cations present in the PM2.5. Taking into account the above result may suggest that the particles had alkaline characteristics during this period of the year. It is important to note that these results can vary if other ion species and even other particle sizes are taken into account. Figure 4 shows the results of this analysis considering all campaign study data.

\subsection{Cluster Analysis Applied to Components Associated with PM2.5}

A multivariate analysis Cluster type was performed to the data set of the composition of anions and cations associated with PM2.5. Ward's method for the formation of groups was applied to standardized variables. The dendrogram allowed for distinguishing two basic groups for integration of anion and cation species (Figure 5). One of them consists primarily of $\mathrm{Cl}^{-}, \mathrm{Na}^{+}, \mathrm{Mg}^{2+}$ and $\mathrm{Ca}^{2+}$. It is known that species such as $\mathrm{Mg}^{2+}$ and $\mathrm{Ca}^{2+}$ mainly come from a geological origin. The presence of $\mathrm{Cl}^{-}$and $\mathrm{Na}^{+}$in the group coincides with the results of the probable presence of compounds such as sodium chloride, magnesium chloride and calcium chloride, which were described in previous sections. In this first group $\mathrm{NO}_{3}^{-}$and PM2.5 are close, which, for the latter, may 


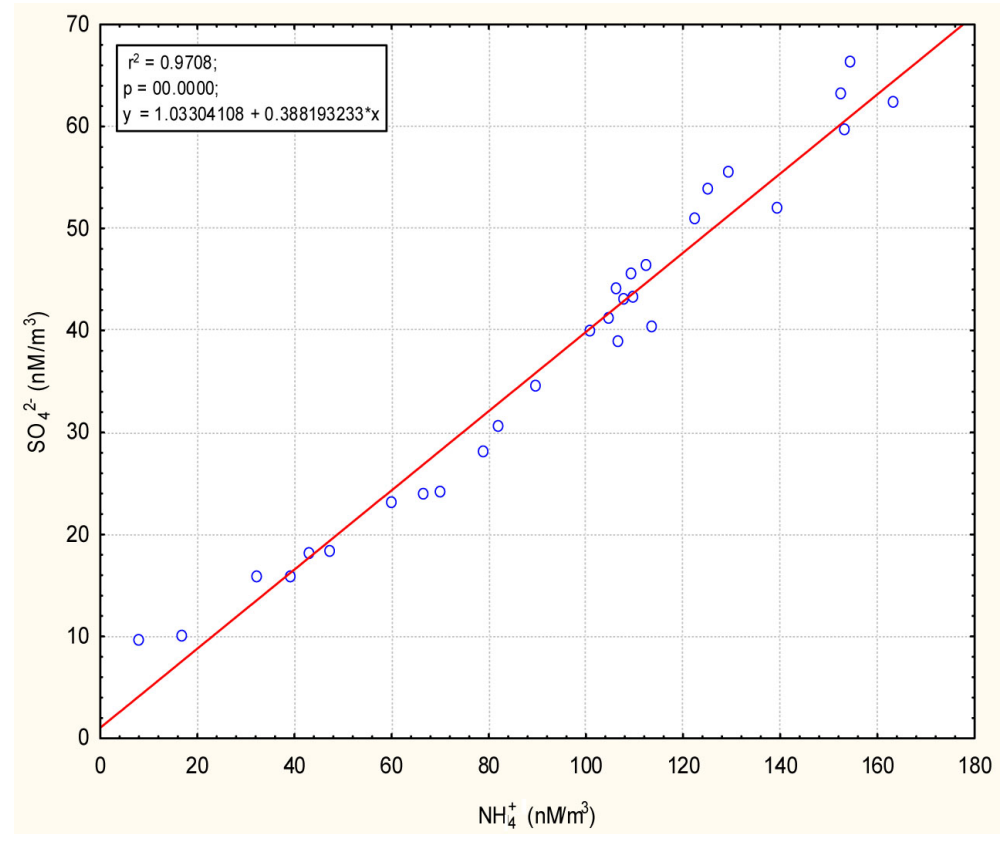

Figure 3. Neutralization of the total amount of sulfate and ammonium.

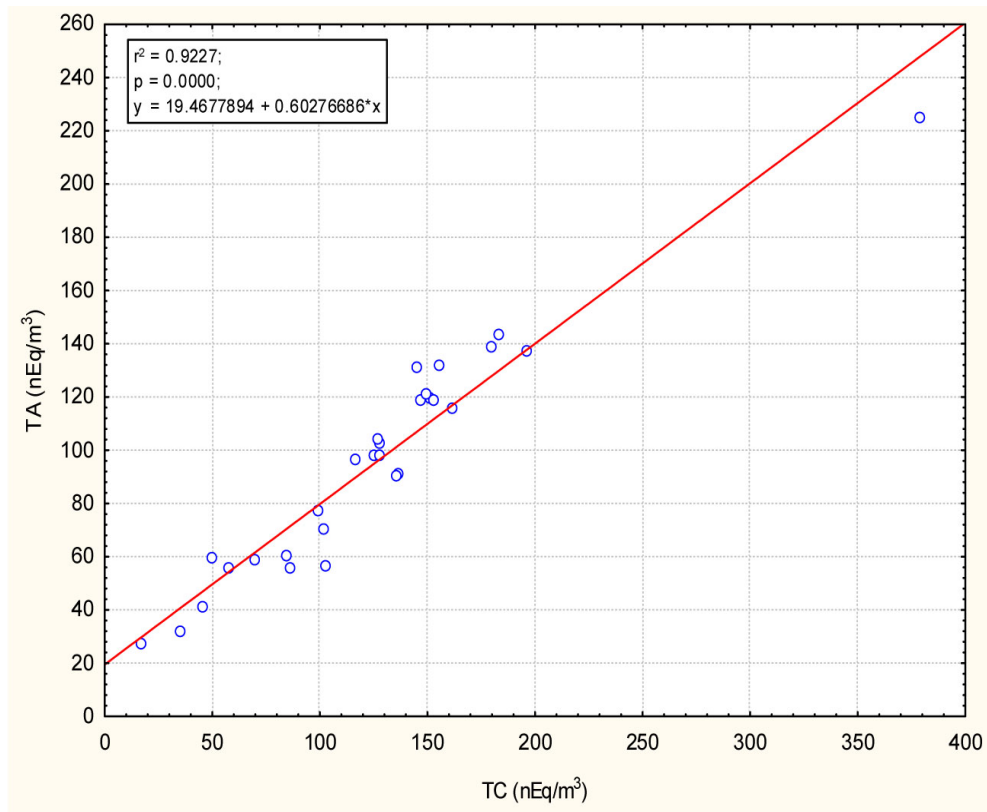

Figure 4. Ion balance at Cuernavaca. The slope below the unity correlations indicate particulates with alkalinity properties.

suggest that the geological material is probably an important component in the source of such particles. This is based on the positive correlation, although moderate, of the particles with $\mathrm{Ca}^{2+}$ (Table 3), with respect to the other ions.

The second group consists mainly of $\mathrm{SO}_{4}^{2-}$ and $\mathrm{NH}_{4}^{+}$, species of secondary origin and the two most abundant in the present study. In both cases, they are derived from precursors originating from various combustion processes, especially from petroleum derivatives. $\mathrm{K}^{+}$and $\mathrm{PO}_{4}^{3-}$ conform to this group by the probable relationship of neutralization or a common origin with nitrates and sulfates, taking into account the respective significant correlation coefficients, showed in Table 3. 


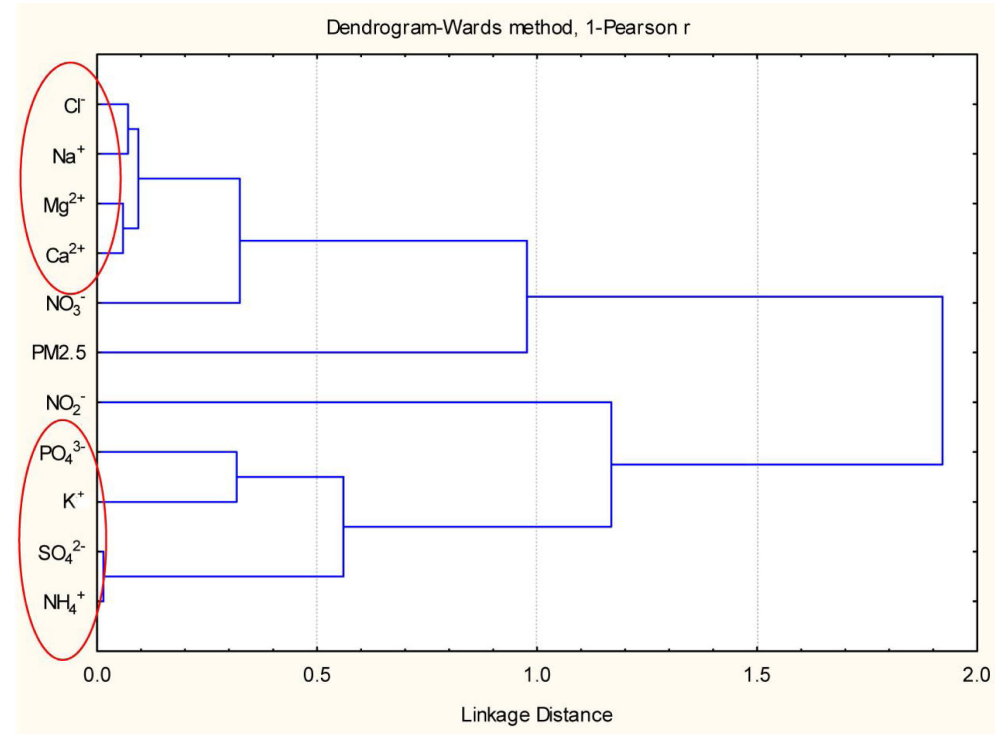

Figure 5. Ward's method of cluster analysis with Pearson for the elements associated with PM2.5.

\section{Conclusions}

The trajectories of the winds in the urban area of Cuernavaca indicate that during the study period, the north area (AUSM) may have been influenced by pollutants from the southeast and east of the city.

The results obtained suggest that the PM2.5 concentration is very homogeneous in Cuernavaca (average concentration $\left.37 \mu \mathrm{g} \cdot \mathrm{m}^{-3}\right)$.

With respect to the ion concentration the results indicate that the most abundant species are sulfate and ammonium. It is also important to note that the concentration of anions and cations in Cuernavaca is very similar, suggesting common sources and/or similar mechanisms.

Meanwhile, the ion balance reveals that in the city of Cuernavaca aerosols presented alkaline characteristics during the study period; this means that the amount of anions was not sufficient to neutralize the ammonium and other cation species.

\section{Acknowledgements}

The authors would like to express their appreciation to Winston Smith of the Peace Corps for the revision of this paper, to the Air Quality Monitoring Network of the State of Morelos (RAMAMOR, for its acronym in English) for allowing the installment of the equipment in their locations Special thanks also to National Council for Science and Technology (CONACyT, for its acronym in English) for the financial support in this project.

\section{References}

[1] Twomey, S. (1991) Aerosols, Clouds, and Radiation. Atmospheric Environment, 25, 2435-2442. http://dx.doi.org/10.1016/0960-1686(91)90159-5

[2] Charlson, R.J., Schwartz, S.E., Hales, J.M., Cess, R.D., Coakley Jr., J.A., Hansen, J.E. and Hofmann, D.J. (1992) Climate Forcing by Anthropogenic Aerosols. Science, 255, 423-430. http://dx.doi.org/10.1126/science.255.5043.423

[3] Andreae, M.O. (1995) Climatic Effects of Changing Atmospheric Aerosol Levels. In: Henderson-Sellers, A., Ed., World Survey of Climatology, Vol. 16, Future Climates of the World, Elsevier, Amsterdam, 341-392.

[4] US Environmental Protection Agency (1999) National Air Quality and Missions Trends Report; 454/R-011-004. US Environmental Protection Agency, Washington DC.

[5] Schwartz, S.E. (1996) The Whitehouse Effect-Shortwave Radiative Forcing of Climate by Anthropogenic Aerosols: An Overview. Journal of Aerosol Science, 27, 359-383. http://dx.doi.org/10.1016/0021-8502(95)00533-1

[6] Ramanathan, V., Crutzen, P.J., Kiehl, J.T. and Rosenfeld, D. (2001) Atmosphere, Aerosols, Climate, and the Hydrological Cycle. Science, 294, 2119-2124. http://dx.doi.org/10.1126/science.1064034 
[7] Menon, S., Hansen, J., Nazarenko, L. and Luo, Y. (2002) Climate Effects of Elemental Carbon Aerosols in China and India. Science, 297, 2250-2253. http://dx.doi.org/10.1126/science.1075159

[8] Brook, J.R., Dann, T.F. and Burnett, R.T. (1997) The Relationship among TSP, PM10, PM2.5 and Inorganic Constituents of Atmospheric Particulate Matter at Multiple Canadian Locations. Journal of Air \& Waste Management Association, 47, 2-19. http://dx.doi.org/10.1080/10473289.1997.10464407

[9] Lee, J.H., Kim, Y.P., Moon, K.C., Kim, H.K. and Lee, C.B. (2001) Fine Particle Measurement at Two Background Sites in Korea between 1996 and 1997. Atmospheric Environment, 35, 635-643. http://dx.doi.org/10.1016/S1352-2310(00)00378-2

[10] Wang, G., Wang, H., Yu, Y., Gao, S., Feng, J., Gao, S. and Wang, L. (2003) Chemical Characterization of Water-Soluble Components of PM10 and PM2.5 Atmospheric Aerosols in Five Locations of Nanjing, China. Atmospheric Environment, 37, 2893-2903. http://dx.doi.org/10.1016/S1352-2310(03)00271-1

[11] Cheng, M.T., Lin, Y.C., Chio, C.P., Wang, C.F. and Kuo, C.Y. (2005) Characteristics of Aerosols Collected in Central Taiwan during Asian Dust Event in Spring 2000. Chemosphere, 61, 1439-1450. http://dx.doi.org/10.1016/j.chemosphere.2005.04.120

[12] Yin, J. and Harrison, R.M. (2008) Pragmatic Mass Closure Study for $\mathrm{PM}_{1.0}, \mathrm{PM}_{2.5}$ and $\mathrm{PM}_{10}$ at Roadside, Urban Background and Rural Sites. Atmospheric Environment, 42, 980-988. http://dx.doi.org/10.1016/j.atmosenv.2007.10.005

[13] Cheng, Y., Lee, S.C., Ho, K.F. and Fung, K. (2010) Positive Sampling Artifacts in Particulate Organic Carbon Measurements in Roadside Environment. Environmental Monitoring and Assessment, 168, 645-656. http://dx.doi.org/10.1007/s10661-009-1140-1

[14] Ito, K., Xue, N. and Thurston, G. (2004) Spatial Variation of $\mathrm{PM}_{2.5}$ Chemical Species and Sources-Apportioned Mass Concentration in New York City. Atmospheric Environment, 38, 5269-5282. http://dx.doi.org/10.1016/j.atmosenv.2004.02.063

[15] Hueglin, C., Gehrig, R., Baltensperger, U., Gysel, M., Monn, C. and Vonmont, H. (2005) Chemical Characterisation of $\mathrm{PM}_{2.5}, \mathrm{PM}_{10}$ and Coarse Particles at Urban, Near-City and Rural Sites in Switzerland. Atmospheric Environment, 39, 637-651. http://dx.doi.org/10.1016/j.atmosenv.2004.10.027

[16] Bell, M.L., Dominici, F., Ebisu, K., Zeger, S.L. and Samet, J.M. (2007) Spatial and Temporal Variation in $\mathrm{PM}_{2.5}$ Chemical Composition in the United States for Health Effects Studies. Environment Health Perspectives, 115, 989-995. http://dx.doi.org/10.1289/ehp.9621

[17] Báez, P.A., García, M.R., Torres, B.M., Padilla, H.G., Belmont, R.D., Amador, M.O. and Villalobos-Pietrini, R. (2007) Origin of Trace Elements and Inorganic Ions in $\mathrm{PM}_{10}$ Aerosols to the South of Mexico City. Atmospheric Research, 85, 52-63. http://dx.doi.org/10.1016/j.atmosres.2006.11.003

[18] Clapp, L.J. and Jenkin, M.E. (2001) Analysis of the Relationship between Ambient Levels of $\mathrm{O}_{3}$, $\mathrm{NO}_{2}$ and $\mathrm{NO}$ as a Function of $\mathrm{NO}_{\mathrm{x}}$ in the UK. Atmospheric Environment, 35, 6391-6405. http://dx.doi.org/10.1016/S1352-2310(01)00378-8

[19] Hodgson, E. (2004) A Textbook of Modern Toxicology. Wiley-Interscience, Hoboken. http://dx.doi.org/10.1002/0471646776

[20] Aldabe, J., Elustondo, D., Santamaría, C., Lasheras, E., Pandolfi, M., Alastuey, A., Querol, X. and Santamaría, J.M. (2011) Chemical Characterisation and Source Apportionment of $\mathrm{PM}_{2.5}$ and $\mathrm{PM}_{10}$ at Rural, Urban and Traffic Sites in Navarra (North of Spain). Atmospheric Research, 102, 191-205. http://dx.doi.org/10.1016/j.atmosres.2011.07.003

[21] Baker, K.R. and Foley, K.M. (2011) A Nonlinear Regression Model Estimating Single Source Concentrations of Primary and Secondarily Formed $\mathrm{PM}_{2.5}$. Atmospheric Environment, 45, 3758-3767. http://dx.doi.org/10.1016/j.atmosenv.2011.03.074

[22] Hagler, G.S.W., Bergin, M.H., Smith, E.A. and Dibb, J.E. (2007) A Summer Time Series of Particulate Carbon in the Air and Snow at Summit, Greenland. Journal of Geophysical Research: Atmospheres, 112, Published Online. http://dx.doi.org/10.1029/2007JD008993

[23] Koçak, M., Mihalopoulos, N. and Kubilay, N. (2007) Chemical Composition of the Fine and Coarse Fraction of Aerosols in the Northeastern Mediterranean. Atmospheric Environment, 41, 7351-7368. http://dx.doi.org/10.1016/j.atmosenv.2007.05.011

[24] Teixeira, E.C., Meira, L., de Santana, E.R.R. and Wiegand, F. (2009) Chemical Composition of $\mathrm{PM}_{10}$ and $\mathrm{PM}_{2.5}$ and Seasonal Variations in South Brazil. Water, Air, Soil Pollution, 199, 261-275 http://dx.doi.org/10.1007/s11270-008-9876-8

[25] Yang, H., Yu, J.Z., Ho, S.S., Xu, J., Wu, W.S., Wan, C.H., et al. (2005) The Chemical Composition of Inorganic and Carbonaceous Materials in $\mathrm{PM}_{2.5}$ in Nanjing, China. Atmospheric Environment, 39, 3735-3749. http://dx.doi.org/10.1016/j.atmosenv.2005.03.010

[26] Wang, Y., Zhuang, G.S., Tang, A.H., Yuan, H., Sun, Y.L., Chen, S. and Zheng, A.H. (2005) The Ion Chemistry and 
the Source of $\mathrm{PM}_{2.5}$ Aerosol in Beijing. Atmospheric Environment, 39, 3771-3784. http://dx.doi.org/10.1016/j.atmosenv.2005.03.013

[27] Rattigan, V.O., Hogrefeb, O., Feltona, D.H., Schwabb, J.J., Roychowdhuryb, K.U., Husainc, L., et al. (2006) MultiYear Urban and Rural Semi-Continuous $\mathrm{PM}_{2.5}$ Sulfate and Nitrate Measurements in New York State: Evaluation and Comparison with Filter Based Measurements. Atmospheric Environment, 40, 192-205. http://dx.doi.org/10.1016/j.atmosenv.2005.12.071 
Scientific Research Publishing (SCIRP) is one of the largest Open Access journal publishers. It is currently publishing more than 200 open access, online, peer-reviewed journals covering a wide range of academic disciplines. SCIRP serves the worldwide academic communities and contributes to the progress and application of science with its publication.

Other selected journals from SCIRP are listed as below. Submit your manuscript to us via either submit@scirp.org or Online Submission Portal.
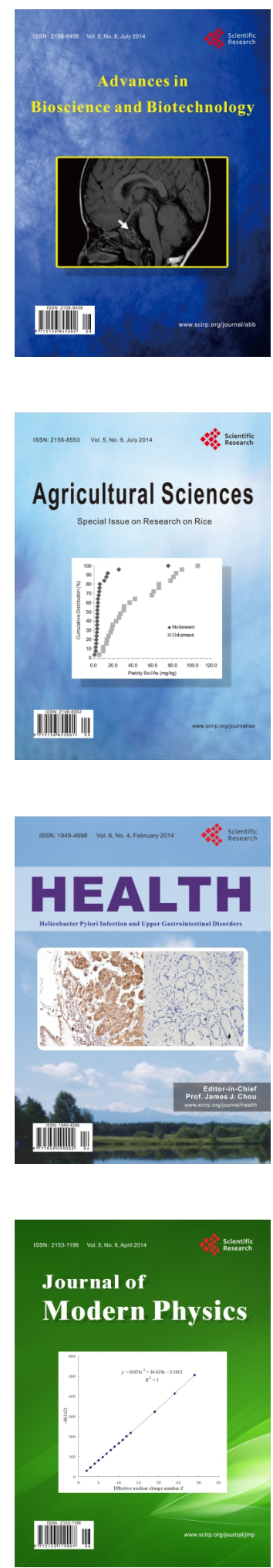
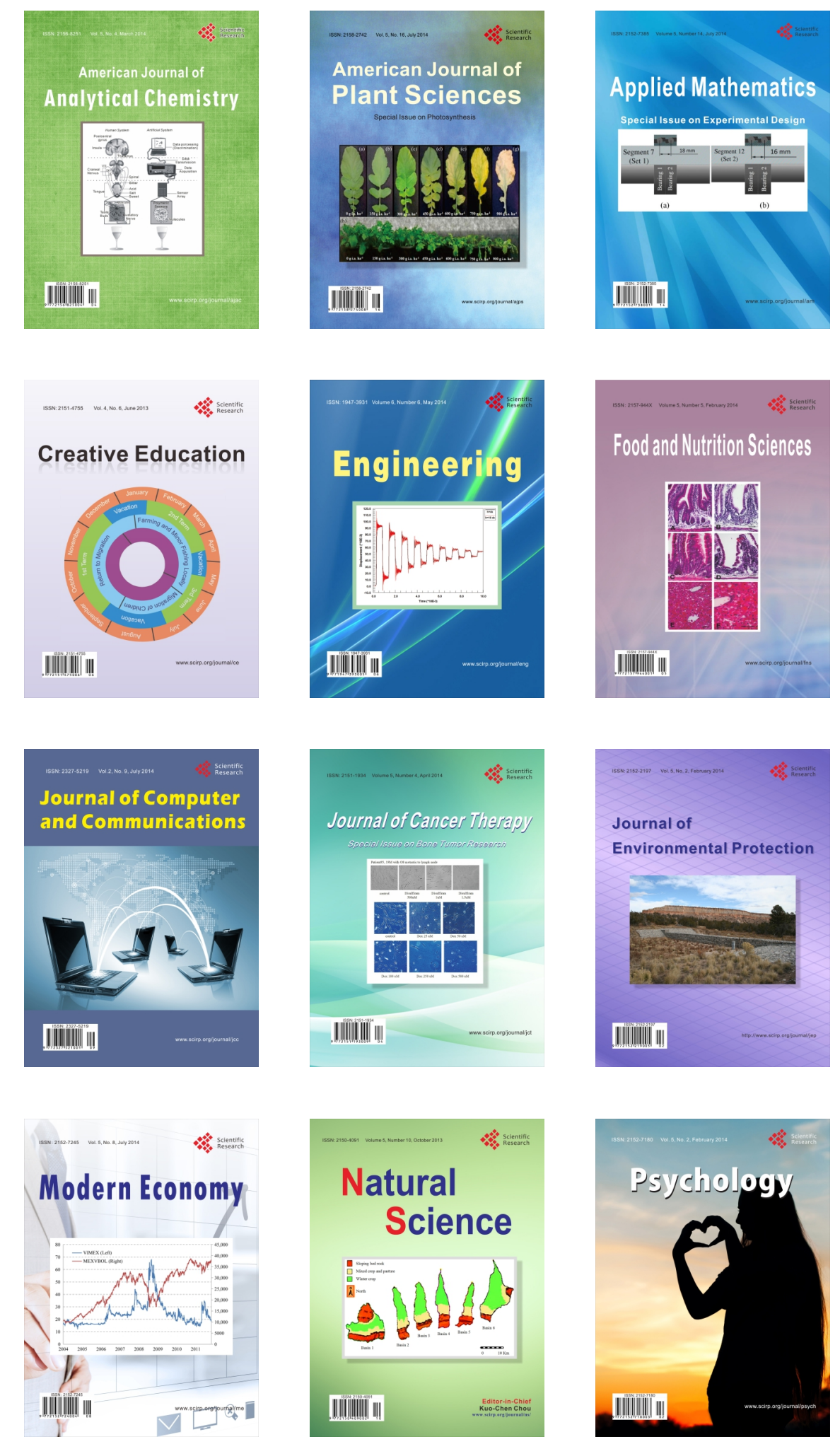